\title{
PRAVNI OKVIR ZA OBNOVLJIVE IZVORE ENERGIJE U PRAVU EUROPSKE UNIJE
}

UDK: 34:620.9(4-6 EU)

DOI: $10.31141 /$ zrpfs.2020.57.137.803

Pregledni znanstveni rad

Primljeno: 15. 1. 2020.

\begin{abstract}
Namjera ovog rada jest istražiti pravni okvir za obnovljive izvore energije u pravu Europske unije. U tom cilju, bit će prikazana i određena osnovna pitanja u europskoj politici u području obnovljive energije. Središnji dio rada predstavlja prikaz sekundarnog prava EU-a za obnovljive izvore energije, a posebna pozornost pružit će se i pitanjima njegova povijesnog razvoja, kao i novoj Direktivi (EU) 2018/2001 o promicanju uporabe energije iz obnovljivih izvora, kojom je preinačena Direktiva 2009/28/EZ. U navedenim razmatranjima uzet će se u obzir i utjecaj prava okoliša na energetsko pravo EU-a. U zadnjem dijelu rada istražuje se praksa Suda Europske unije u području obnovljivih izvora energije.
\end{abstract}

Ključne riječi: obnovljivi izvori energije, Direktiva (EU) 2018/2001, Direktiva 2009/28/EZ, praksa Suda Europske unije, zaštita okoliša

\section{UVOD ${ }^{3}$}

Prema Izvješću Glavnog tajništva Ujedinjenih naroda o ciljevima održivog razvoja za 2018. godinu, u razdoblju od 2000. do 2016. godine udio svjetskog stanovništva s pristupom električnoj energiji povećan je sa 78 na 87 posto, pri čemu je stopa elektrifikacije u urbanim područjima dosegla 97, a u ruralnim područjima iznosi 76 posto. Unatoč navedenom rastu, iz izvješća proizlazi da gotovo jedna milijarda ljudi još uvijek živi bez pristupa električnoj energiji, a projekcije rasta stope elektrifikacije upućuju na zaključak da cilj univerzalne elektrifikacije neće biti

1 Ivor Šantek, mag. iur., e-mail: ivor.santek@gmail.com

2 Dr. sc. Lana Ofak, izv. prof., e-mail: lana.ofak@pravo.hr

3 Ovaj rad temelji se na diplomskom radu Ivora Šanteka, koji je izrađen pod mentorstvom Lane Ofak, a izložen je na konferenciji održanoj 12. studenoga 2019. na Pravnom fakultetu Sveučilišta u Zagrebu u okviru bilateralnog hrvatsko-slovenskog projekta „Pravna analiza postojećeg energetskog zakonodavstva u Republici Hrvatskoj i preporuke za poboljšanje“. 
Ivor Šantek, mag. iur. i dr. sc. Lana Ofak: Pravni okvir za obnovljive izvore energije u pravu Europske unije Zbornik radova Pravnog fakulteta u Splitu, god. 57, 3/2020, str. 803-827

ostvaren do 2030. godine. ${ }^{4}$ Nadalje, Međunarodna agencija za energiju ${ }^{5}$ u Izvješću o stanju globalne energije i $\mathrm{CO} 2$ navodi da se globalni trend rasta potrošnje energije nastavlja, pri čemu je potrošnja u 2018. godini porasla za 2,3\%, što je gotovo dvostruko povećanje u odnosu na prosječnu stopu rasta potrošnje energije od 2010. godine. ${ }^{6}$

Uzimajući u obzir navedene podatke o globalnom rastu energetskih potreba, kao i projekcije gospodarskog ${ }^{7} \mathrm{i}$ demografskog ${ }^{8}$ rasta, može se zaključiti da je organizacija učinkovitog upravljanja energetskim resursima jedno od najznačajnijih pitanja za razvoj čovječanstva. Pri tome značajan problem predstavlja energetska ovisnost o fosilnim gorivima, na koja se, prema podacima za 2017. godinu, odnosi 79,7 \% ukupne potrošnje energije, dok se $18,1 \%$ odnosi na obnovljive izvore energije (od čega se 10,6 \% odnosi na moderne obnovljive izvore kao što su solarna energija, energija vjetra, hidroenergija ili geotermalna energija), a 2,2 \% na nuklearnu energiju. ${ }^{9}$ Prevladavajuća uporaba fosilnih goriva za zadovoljavanje energetskih potreba usko je povezana i s problematikom klimatskih promjena. Oslanjanje na fosilna goriva u dosadašnjoj mjeri moglo bi imati značajne negativne posljedice na Zemljine klimatske sustave, što podrazumijeva i problem globalne i regionalne nestašice hrane, kao i značajno izumiranje biljnih i životinjskih vrsta. Naime, fosilna goriva predstavljaju najveći antropogeni izvor emisija stakleničkih plinova, a industrija fosilnih goriva i proizvodi te industrije odgovorni su, prema podacima za 2015. godinu, za $91 \%$ svjetskih industrijskih emisija stakleničkih plinova i za oko $70 \%$ svih antropogenih emisija stakleničkih plinova. ${ }^{10}$ Stoga je zadaća energetskog

4 The Sustainable Development Goals Report 2018, United Nations, New York, 2018., http:// unstats.un.org/sdgs/files/report/2018/TheSustainableDevelopmentGoalsReport2018-EN.pdf, pristup: 23. kolovoza 2019., str. 22-23.

5 Međunarodna agencija za energiju (International Energy Agency) međuvladina je organizacija koja djeluje u okviru sustava Organizacije za ekonomsku suradnju i razvoj (OECD) s ciljem savjetovanja država članica u području energetske politike.

6 Global Energy \& CO2 Status Report: The latest trends in energy and emissions in 2018, http:// www.iea.org/geco/, pristup: 23. kolovoza 2019.

7 OECD predviđa ublažavanje trenda globalnog rasta BDP-a sa sadašnjih 3,5 \% na $2 \%$ do 2060. godine. ,The Long View: Scenarios for the World Economy to 2060“, OECD Economic Policy Paper, July 2018, No. 22, OECD, http://read.oecd-ilibrary.org/economics/the-long-view_b4f4e03e-en\#page1, pristup: 23. kolovoza 2019., str. 5.

8 Izvješće Glavnog tajništva Ujedinjenih naroda o projekcijama rasta svjetskog stanovništva za 2019. godinu predviđa mogućnost da će do 2030. godine svijet doseći 8,5 milijardi stanovnika, do 2050. godine 9,7 milijardi stanovnika, a do 2100. godine 10,9 milijardi stanovnika. World Population Prospects 2019: Highlights, United Nations, New York, 2019., http://population.un.org/wpp/Publications/Files/ WPP2019_Highlights.pdf, pristup: 23. kolovoza 2019., str. 1.

9 Renewables 2019 Global Status Report, REN21, 2019., http://www.ren21.net/wp-content/ uploads/2019/05/gsr_2019_full_report_en.pdf, pristup: 23. kolovoza 2019., str. 31. Prema navedenom izvješću i podacima koji se odnose na 2016. godinu, $51 \%$ potrošnje energije odnosi se na sektor grijanja i hlađenja (od čega 9,8 \% iz obnovljivih izvora), $32 \%$ potrošnje energije odnosi se na sektor prijevoza (od čega 3,3\% iz obnovljivih izvora), a $17 \%$ potrošnje energije odnosi se na elektroenergetski sektor (od čega $26 \%$ iz obnovljivih izvora).

10 The Carbon Majors Database: CDP Carbon Majors Report 2017, CDP, http:// b8f65cb373b1b7b15feb-c70d8ead6ced550b4d987d7c03fcdd1d.ssl.cf3.rackcdn.com/cms/reports/ documents/000/002/327/original/Carbon-Majors-Report-2017.pdf, pristup: 23. kolovoza 2019., str. 7. 
prava, kao grane prava koja uređuje pitanja upravljanja energetskim resursima, ${ }^{11}$ da postavi pravne temelje koji će omogućiti kako zadovoljavanje rastućih energetskih potreba, tako i osiguravanje dostupnosti tehnologija za niskougljičnu proizvodnju električne energije uz najmanju štetu za okoliš. Posljednje ujedno predstavlja i jedan od najznačajnijih današnjih izazova, osobito u kontekstu međunarodnih nastojanja suočavanja s klimatskim promjenama. ${ }^{12}$

Prema tome, energetsko pravo ima značajnu ulogu u poticanju, omogućavanju i usmjeravanju energetske tranzicije, s ekonomije fokusirane na fosilna goriva, na niskougljičnu ekonomiju. Takva tranzicija prijeko je potrebna pretpostavka za smanjenje i stabilizaciju atmosferskih koncentracija stakleničkih plinova, bez čega neće biti moguce ostvariti cilj ograničavanja rasta globalne temperature do $2^{\circ} \mathrm{C} \mathrm{u}$ odnosu na predindustrijske razine, što je u znanstvenoj i političkoj zajednici široko prihvaćena granica za izbjegavanje teških i potencijalno nepopravljivih posljedica za prirodne (e.g. atmosferske, biološke i geološke) i ljudske (e.g. ekonomske, socijalne) sustave. Kako bi se navedeni cilj mogao ostvariti, potrebna je, s jedne strane, modifikacija načina korištenja fosilnih goriva, a s druge, ekspanzija obnovljivih izvora energije. ${ }^{13}$

U razmatranju uloge energetskog prava u takvoj tranziciji, pa tako i u odnosu na regulaciju obnovljivih izvora energije, potrebno je uzeti u obzir da energetskopravna regulacija djeluje na tri razine, i to na međunarodnopravnoj, nacionalnoj te lokalnoj razini.$^{14}$ Osobito je uočljiv, zadržavajući se na međunarodnopravnoj razini regulacije, nedostatak posebnog međunarodnog ugovora koji bi uređivao materiju međunarodnog energetskog prava u odnosu na obnovljive izvore energije. ${ }^{15}$

Nedostatak institucionalnog okvira za obnovljive izvore energije često nailazi na kritiku, pri čemu se smatra da, uzimajući u obzir postojeće razine globalnih emisija stakleničkih plinova te uporabe fosilnih goriva, čak i općeprihvaćeni međunarodnopravni akt koji bi utvrdio ambiciozne i pravno obvezujuće granice za emisije stakleničkih plinova nije dostatan za izbjegavanje teških negativnih posljedica klimatskih promjena. Smatra se da je za ostvarenje takvog cilja nužan i odgovarajući globalni institucionalni okvir koji će omogućiti razdvajanje gospodarskog i socijalnog razvoja od emisija stakleničkih plinova te utrti put globalnoj niskougljičnoj ekonomiji. ${ }^{16}$ Također, ističe se da postojeći međunarodnopravni

11 Heffron, Raphael J., Energy Law: An Introduction, Springer Cham, Heidelberg, 2015., str. 1.

12 Ferguson, Ross; Wilkinson, William; Hill, Robert, „Electricity use and economic development“, Energy Policy, god. 28, br. 13, 2000., str. 934.

${ }_{13}$ V. primjerice Knopf, Brigitte; Edenhofer, Ottmar; Flachsland, Christian; Kok, Marcel T. J.; LotzeCampen, Hermann; Luderer, Gunnar; Popp, Alexander; van Vuuren, Detlef P., „Managing the LowCarbon Transition - From Model Results to Policies“, The Energy Journal, god. 31, posebni br. 1, 2010., str. 223-224.

${ }^{14}$ Heffron, Raphael J., op. cit. (bilj. 9), str. 15.

15 Ibid., str. 18.

16 Messner, Dirk; Schellnhuber, John; Rahmstorf, Stefan; Klingenfeld, J. Daniel, ,,The budget approach - a framework for a global transformation towards a low carbon economy“, u: Koch, Hans-Joachim; König, Doris; Sanden, Joachim; Verheyen, Roda (ur.), Climate Change and Environmental Hazards Related to Shipping. An International Legal Framework. Proceedings of the Hamburg International Environmental Law Conference 2011, Martinus Nijhoff Publishers, Leiden, 2013., str. 24-25. 
Ivor Šantek, mag. iur. i dr. sc. Lana Ofak: Pravni okvir za obnovljive izvore energije u pravu Europske unije Zbornik radova Pravnog fakulteta u Splitu, god. 57, 3/2020, str. 803-827

okvir predstavlja propuštenu priliku za utvrđivanje prave i učinkovite međunarodne klimatske politike te da pruža nedovoljno pozornosti izravnoj regulaciji obnovljivih izvora energije. ${ }^{17}$

Upravo u kontekstu navedenog međunarodnopravnog deficita, koji za posljedicu ima prepuštanje inicijative niskougljične tranzicije nacionalnim razvojnim programima ${ }^{18}$ relevantna je regulatorna djelatnost Europske unije (dalje u radu: EU) u području energetskog prava, kao i njezina energetska politika, što će ujedno biti predmetom ovog rada.

Naime, ističe se da je pravo EU-a autonomno nadnacionalno pravo koje se razlikuje od prava njegovih država članica, a da je jedno od njegovih osnovnih obilježja svojstvo da, neovisno o području regulacije, djeluje ograničavajuće na pravne poretke država članica, odnosno da postavlja granice regulacije i pravne interpretacije nacionalnog prava. ${ }^{19}$ Dakle, pravo EU-a ograničava regulatornu autonomiju na nacionalnoj razini te u tom smislu EU predstavlja nadnacionalni pravni i politički okvir koji omogućuje progresivno djelovanje i u području energetskog prava te energetske politike, čime se otvara mogućnost za inovacije koje nedostaju u području međunarodnog energetskog prava. ${ }^{20}$

Osim toga, analiza energetskog prava i politike EU-a u području obnovljivih izvora energije te niskougljične tranzicije značajna je $\mathrm{i}$ ako se uzme $\mathrm{u}$ obzir odgovornost država članica EU-a u odnosu na povijesne emisije stakleničkih plinova. Naime, prema određenim modelima povijesnih analiza emisija stakleničkih plinova od začetaka industrijske revolucije do danas, 25 država članica EU-a ${ }^{21}$ odgovorno je za $28 \%$ svih povijesnih emisija stakleničkih plinova od 1750. (kao godine od koje su dostupni podaci o emisijama) do 2005. godine. Iz dostupnih podataka proizlazi da su države članice EU-a najveći povijesni emitent stakleničkih plinova, dok su najveći individualni emitent Sjedinjene Američke Države, odgovorne za 20,7 \% svih emisija $\mathrm{u}$ istom vremenskom razdoblju. ${ }^{22}$ Utvrđivanje udjela u povijesnim emisijama od iznimnog je značaja zato što se smatra da će većina posljedica klimatskih promjena u nadolazećim desetljećima biti rezultat povijesnih emisija za koje su odgovorne upravo razvijene države. Pri tome nisu sve države jednako izložene posljedicama klimatskih promjena. Najranjivijima se smatraju one države koje su najmanje

17 Bruce, Stuart, ,International Law and Renewable Energy: Facilitating Sustainable Energy for All?“, Melbourne Journal of International Law, god. 14, br. 1, 2013., str. 17-18.

18 Epiney, Astrid, „Discussion summary. Working group: initiatives on an EU and on a national level“, u: Koch, Hans-Joachim; König, Doris; Sanden, Joachim; Verheyen, Roda (ur.), Climate Change and Environmental Hazards Related to Shipping. An International Legal Framework. Proceedings of the Hamburg International Environmental Law Conference 2011, Martinus Nijhoff Publishers, Leiden, 2013., str. 103.

19 Ćapeta, Tamara; Rodin, Siniša, Osnove prava Europske unije, II. izmijenjeno i dopunjeno izdanje, Narodne novine, Zagreb, 2011., str. 3-4.

20 Bruce, Stuart, op. cit. (bilj. 15), str. 23.

21 Podaci se odnose na razdoblje koje prethodi proširenju EU-a 2007. godine, odnosno 2013. godine.

22 Dellink, Rob; den Elzen, Michel; Aiking, Harry; Bergsma, Emmy; Berkhout, Frans; Dekker, Thijs; Gupta, Joyeeta, ,Sharing the burden of financing adaptation to climate change“, Global Environmental Change, god. 19, br. 4, 2009., str. 415-417. 
doprinijele povijesnim emisijama, čime se ujedno postavlja pitanje odgovornosti razvijenih država, kako u pogledu smanjenja emisija stakleničkih plinova, tako i u pogledu snošenja troškova adaptacije u odnosu na posljedice klimatskih promjena. ${ }^{23}$

Nadalje, u prilog analizi europskog energetskog prava i politike govori i važna uloga EU-a u međunarodnom energetskom sektoru, zbog koje i brojne treće zemlje razvijaju energetsko pravo i politiku pod utjecajem EU-a i njegovih država članica. ${ }^{24}$ EU je, zbog usvojenih programa i politika, na međunarodnoj razini pozicioniran kao nositelj inicijative u pogledu suočavanja s klimatskim promjenama, pri čemu značajno utječe na oblikovanje međunarodne energetske i klimatske politike te prava. ${ }^{25}$

Iz navedenih razloga, europsko energetsko pravo i politika predstavljaju pogodan objekt za analizu suvremenih nastojanja u poticanju energetske tranzicije te suočavanju s klimatskim promjenama. ${ }^{26}$ Stoga je namjera ovog rada istražiti pravni okvir za obnovljive izvore energije u pravu EU-a. U tom cilju, bit cee prikazana i određena osnovna pitanja u europskoj politici u području obnovljive energije. Središnji dio rada predstavlja prikaz sekundarnog prava EU-a za obnovljive izvore energije, a posebna pozornost pružit će se i pitanjima njegova povijesnog razvoja. U navedenim razmatranjima uzet će se u obzir i utjecaj prava okoliša na energetsko pravo EU-a. U zadnjem dijelu rada istražuje se praksa Suda Europske unije u području obnovljivih izvora energije.

\section{POLITIKA EUROPSKE UNIJE ZA OBNOVLJIVE IZVORE ENERGIJE}

Heffron i Talus tvrde da je teško razdvojiti analizu energetskog prava od energetske politike jer su energetsko pravo i politika u mnogo čemu isprepleteni. ${ }^{27}$ Zbog toga, u svrhu kontekstualizacije regulatornih tendencija u pravu EU-a u odnosu na obnovljive izvore energije, ovaj dio rada sadrži prikaz određenih aspekata europske energetske politike, u mjeri u kojoj je ona usmjerena na promicanje energetske učinkovitosti, uštede energije te, osobito, razvoja novih i obnovljivih oblika energije, što predstavlja jedan od ciljeva energetske politike EU-a prema čl.

23 Ibid., str. 411.

24 Heffron, Raphael J., op. cit. (bilj. 9), str. 16.

25 Schreurs, Miranda A.; Tiberghien, Yves, „Multi-Level Reinforcement: Explaining European Union Leadership in Climate Change Mitigation“, Global Environmental Politics, god. 7, br. 4, 2007. str. 19-20.

26 Slično i Dreger, Jonas, The European Commission's Energy and Climate Policy. A Climate for Expertise?, Palgrave Macmillan, Basingstoke, 2014., str. 9., u pogledu analize energetske i klimatske politike EU-a.

27 Heffron, Raphael J.; Talus, Kim, ,The development of energy law in the 21st century: a paradigm shift?“, The Journal of World Energy Law \& Business, god. 9, br. 3, 2016., str. 192. 
Ivor Šantek, mag. iur. i dr. sc. Lana Ofak: Pravni okvir za obnovljive izvore energije u pravu Europske unije Zbornik radova Pravnog fakulteta u Splitu, god. 57, 3/2020, str. 803-827

194. st. 1. t. c Ugovora o funkcioniranju Europske unije. ${ }^{28}$ Važnost takve analize proizlazi i iz okolnosti da je do 2010. godine EU proizveo više od 350 pravnih instrumenata u području energetske politike. ${ }^{29}$

\subsection{Strategija Europa 2020.}

Strategija Europa 2020. program je EU-a, pokrenut 2010. godine, usmjeren na ostvarivanje pametnog, održivog i uključivog rasta. ${ }^{30}$ Strategijom su predviđena tri cilja u području klimatskih promjena i energije (tzv. „,iljevi 20-20-20“). U pogledu smanjenja emisija stakleničkih plinova predviđen je obvezujući cilj smanjenja emisija od $20 \%$ do 2020. godine u odnosu na razine iz 1990. godine. U pogledu obnovljivih izvora energije predviđen je obvezujući cilj povećanja udjela obnovljive energije u konačnoj energetskoj potrošnji na $20 \%$ do 2020. godine, dok je u odnosu na energetsku učinkovitost predviđen neobvezujući cilj smanjenja primarne energetske potrošnje za $20 \%$ do 2020. godine u odnosu na relevantne projekcije. ${ }^{31}$ Na razini 28 država članica EU-a, obnovljiva energija imala je u 2015. godini udio od 16,7 \% u konačnoj energetskoj potrošnji, dok prema projekcijama za 2020. godinu taj udio varira između 19,4 i 21,8 \%. ${ }^{32}$ Kritika koja se upućuje strategiji Europa 2020. uzima u obzir da, zbog ubrzanog rasta zemalja u razvoju, doprinos EU-a globalnim emisijama stakleničkih plinova pada velikom brzinom, te da će zbog toga utjecaj europskih nastojanja usmjerenih na smanjenje emisija postati marginalan. Naime, iako se smatra da će EU ostvariti cilj povećanja udjela obnovljive energije u konačnoj energetskoj potrošnji, njegovo ostvarenje trebalo bi rezultirati smanjenjem globalnih emisija za samo $0,5 \%$, dok bi ostvarenje cilja smanjenja emisija, pa čak i za $30 \%$, rezultiralo smanjenjem globalnih emisija za samo $1 \% .33$

\subsection{Okvir za klimatsku i energetsku politiku 2030.}

EU je 2014. godine predstavio Okvir za klimatsku i energetsku politiku 2030. Navedenim okvirom predviđen je obvezujući cilj smanjenja emisija stakleničkih

28 Pročišćene verzije Ugovora o Europskoj uniji i Ugovora o funkcioniranju Europske unije, Ugovor o Europskoj uniji (pročišćena verzija), Ugovor o funkcioniranju Europske unije (pročišćena verzija), Protokoli, Prilozi Ugovoru o funkcioniranju Europske unije, Izjave priložene Završnom aktu Međuvladine konferencije na kojoj je donesen Ugovor iz Lisabona potpisan 13. prosinca 2007., Tablice ekvivalenata, SL C 202, 7. VI. 2016., str. 1.

29 Szulecki, Kacper; Fischer, Severin; Gullberg, Anne Therese; Sartor, Oliver, ,Shaping the 'Energy Union': between national positions and governance innovation in EU energy and climate policy“, Climate Policy, god. 16, br. 5, 2016., str. 549.

30 Gros, Daniel; Roth, Felix, The Europe 2020 Strategy: Can it Maintain the EU's Competitiveness in the World?, Centre for European Policy Studies, Brussels, 2012., str. 1.

31 Ibid., str. 70.

32 Cucchiella, Federica; D’Adamo, Idiano; Gastaldi, Massimo, „Future Trajectories of Renewable Energy Consumption in the European Union“, Resources, god. 7, br. 1, 2018., str. 11.

${ }_{33}$ Gros, Daniel; Roth, Felix, op. cit. (bilj. 28), str. 70-72. 
plinova u EU-u za $40 \%$ do 2030. godine u odnosu na razine iz 1990. godine. U pogledu energije iz obnovljivih izvora, predviđen je za države članice obvezujući kolektivni cilj povećanja udjela obnovljive energije u konačnoj energetskoj potrošnji na $27 \%$. Okvirom je predviđen i cilj rasta energetske učinkovitosti od barem $27 \%$, kao i njegova revizija do 2020. godine. Osim toga, kako bi EU mogao kolektivno ispuniti navedene ciljeve, države članice su se usuglasile o potpori provođenju velikoga broja značajnih infrastrukturnih projekata. Ipak, cilj postavljen za energiju iz obnovljivih izvora bio je kritiziran kao neambiciozan, kako od strane nevladinih organizacija, tako i u akademskoj zajednici. ${ }^{34}$ Ciljevi za energiju iz obnovljivih izvora te energetsku učinkovitost revidirani su u okviru energetskog paketa „Čista energija za sve Europljane“, o kojem će više riječi biti kasnije u radu. Navedenim regulatornim paketom postavljen je obvezujući cilj povećanja udjela obnovljive energije u konačnoj energetskoj potrošnji na razini EU-a na 32 $\%$, kao i cilj energetske učinkovitosti od 32,5\%. ${ }^{35}$ Posebno je pitanje i kako će izlazak Ujedinjenog Kraljevstva Velike Britanije i Sjeverne Irske iz EU-a utjecati na ostvarenje ciljeva iz navedenog okvira. ${ }^{36}$

\subsection{Dugoročna energetska strategija EU-a}

EU je utvrdio dugoročni cilj smanjenja emisija stakleničkih plinova do 2050. godine za 80-95 \% u odnosu na razine iz 1990. godine. U svrhu analize izazova koji su povezani s ostvarenjem cilja dekarbonizacije EU-a, uz istovremeno osiguravanje sigurnosti opskrbe energijom te konkurentnosti, Europska komisija je 2011. godine usvojila „Energy Roadmap 2050“. Europska komisija smatra da će paneuropski pristup izazovima u području energije, pružanjem šireg i fleksibilnijeg tržišta za nove proizvode i usluge, povećati sigurnost i solidarnost te smanjiti cijene u usporedbi s paralelnim nacionalnim programima. S druge strane, ističe se da se europska energetska politika ne smije razvijati u izolaciji, odnosno da se mora uzeti u obzir i stanje međunarodne energetske politike, kao i da EU, u implementaciji navedene strategije, mora voditi računa o razvoju i djelovanju trećih zemalja. Nadalje, povećani udio obnovljive energije u razdoblju nakon 2020. godine smatra se jednim od glavnih preduvjeta za razvoj održivog i sigurnog energetskog sustava, a ističe se i važnost dodatnog razvoja tehnologija u području obnovljive energije za smanjenje cijena. ${ }^{37}$

34 Crossley, Penelope, ,The role of renewable energy law and policy in meeting the EU's energy security challenges“, u: Leal-Arcas, Rafael; Wouters, Jan (ur.), Research Handbook on EU Energy Law and Policy, Edward Elgar Publishing Limited, Cheltenham, 2017., str. 482.

352030 Energy Strategy, http://ec.europa.eu/energy/en/topics/energy-strategy-and-energy-union/ 2030-energy-strategy, pristup: 12. kolovoza 2019. Revizija je izvršena 2018. godine.

36 Tako Crossley, Penelope, op. cit. (bilj. 32), str. 483.

37 European Commission, Communication from the Commission to the European Parliament, the Council, the European Economic and Social Committee and the Committee of the Regions: Energy Roadmap 2050, COM(2011) 885 final, Brussels, 15. XII. 2011., http://eur-lex.europa.eu/legal-content/ EN/TXT/PDF/?uri=CELEX:52011DC0885\&from=EN, pristup: 13. kolovoza 2019. 
Europska komisija usvojila je 2018. godine europsku stratešku dugoročnu viziju za prosperitetno, moderno, konkurentno i klimatski neutralno gospodarstvo pod nazivom „Čist planet za sve“. Strategija za svrhu ima potvrditi vodeću ulogu Europe u oblikovanju globalne klimatske politike, kao i predstaviti viziju koja može pomoći da se do 2050. godine postigne nulta neto stopa emisija stakleničkih plinova. Strategijom je predviđeno da bi što opsežnije uvođenje obnovljivih izvora i upotreba električne energije za potpunu dekarbonizaciju energetske opskrbe u Europi mogao biti jedan od glavnih strateških elemenata na kojima se temelji europska energetska tranzicija. Europska komisija navodi da će do 2050. godine više od 80 \% električne energije dolaziti iz obnovljivih izvora energije te da je kompetitivno uvođenje električne energije iz obnovljivih izvora važna prilika za dekarbonizaciju i drugih sektora kao što su grijanje, promet $i$ industrija. Ističe se da o međunarodnoj suradnji ovisi uspjeh EU-a u predvođenju globalne energetske tranzicije te u borbi protiv klimatskih promjena. ${ }^{38}$

\subsection{Energetska unija}

Energetska unija predstavlja najznačajniju ideju u europskoj energetskoj politici, usmjerenu na reformu europskog energetskog upravljanja, politike te regionalne kooperacije, usklađujući ih s dugoročnim europskim ciljevima za zaštitu klime. Smatra se da bi se u okviru energetske unije mogao razriješiti značajni paradoks europske energetske politike, tj. tenzije između nacionalnog suvereniteta $\mathrm{u}$ energetskom sektoru te perspektive zajednice. ${ }^{39}$ Europska komisija navodi da je cilj energetske unije pružiti potrošačima u EU-u sigurnu, održivu, konkurentnu i povoljnu energiju te da je za ostvarenje tog cilja potrebna temeljita transformacija energetskog sustava u Europi. Kao sastavni dio energetske unije ističe se i ambiciozna klimatska politika koja se temelji, među ostalim, i na energetskoj politici čija je svrha EU učiniti vodećim u svijetu u korištenju energije iz obnovljivih izvora. ${ }^{40}$ Zakonodavni temelj za upravljanje energetskom unijom, prema svojem recitalu 1., predstavlja Uredba (EU) 2018/1999 Europskog parlamenta i Vijeća od 11. prosinca 2018. o upravljanju energetskom unijom i djelovanjem u području

38 Europska komisija, Komunikacija Komisije Europskom parlamentu, Europskom vijeću, Vijeću, Europskom gospodarskom i socijalnom odboru, Odboru regija i Europskoj investicijskoj banci, Čist planet za sve: Europska strateška dugoročna vizija za prosperitetno, moderno, konkurentno i klimatski neutralno gospodarstvo, COM(2018) 773 final, Bruxelles, 28. XI. 2018., http://eur-lex.europa.eu/legalcontent/HR/TXT/PDF/?uri=CELEX:52018DC0773\&from=EN, pristup: 13. kolovoza 2019.

39 Szulecki, Kacper; Fischer, Severin; Gullberg, Anne Therese; Sartor, Oliver, op. cit. (bilj. 27), str. 548.

40 Europska komisija, Paket mjera za energetsku uniju, Komunikacija Komisije Europskom parlamentu, Vijeću, Europskom gospodarskom i socijalnom odboru, Odboru regija te Europskoj investicijskoj banci, Okvirna strategija za otpornu energetsku uniju s naprednom klimatskom politikom, COM(2015) 80 final, Bruxelles, 25. II. 2015., http://eur-lex.europa.eu/resource.html?uri=cellar:1bd46c90bdd4-11e4-bbe1-01aa75ed71a1.0005.02/DOC_1\&format=PDF, pristup: 13. kolovoza 2019. 
klime ${ }^{41}$ kojom je određeno da su energetska sigurnost, unutarnje energetsko tržište, energetska učinkovitost, dekarbonizacija te istraživanje, inovacije i konkurentnost pet dimenzija energetske unije, koje su usko povezane i međusobno se osnažuju (čl. 1. st. 2.).

\section{SEKUNDARNO PRAVO EUROPSKE UNIJE ZA OBNOVLJIVE IZVORE ENERGIJE}

\subsection{Razvoj sekundarnog prava Europske unije za obnovljive izvore energije}

Obnovljivi izvori energije imaju važnu ulogu, kako u osiguravanju sigurnosti opskrbe energijom, smanjenjem ovisnosti o uvozu energije, tako i u borbi protiv klimatskih promjena, smanjenjem emisija stakleničkih plinova. Osim toga, razvoj industrije obnovljive energije u Europi potiče i tehnološki razvoj, zapošljavanje te smanjenje onečišćenja zraka. ${ }^{42}$ Promicanje uporabe energije iz obnovljivih izvora radi smanjenja ovisnosti o uvozu energije te diverzifikacije nacionalnih kombinacija izvora energije država članica tako je osobito značajno u kontekstu problema sigurnost opskrbe energijom. Naime, EU je najveći svjetski uvoznik energije. ${ }^{43}$ Osim toga, od devedesetih godina 20. stoljeća, kada klimatske promjene dolaze u fokus europske politike, promicanje uporabe energije iz obnovljivih izvora smatra se značajnim sredstvom u suočavanju i s tim problemom. ${ }^{44}$ Konačno, smatra se da je usmjeravanje regulatorne djelatnosti EU-a na promicanje uporabe energije iz obnovljivih izvora, kao i energetske učinkovitosti te ušteda, motivirano i željom za širenjem utjecaja EU-a u području energetske politike. ${ }^{45}$ Razvoj europskog prava i politike za obnovljive izvore energije obilježen je tenzijom između pokušaja centralizacije upravljanja u području obnovljive energije na razini EU-a te interesa

${ }_{41}$ Uredba (EU) 2018/1999 Europskog parlamenta i Vijeća od 11. prosinca 2018. o upravljanju energetskom unijom i djelovanjem u području klime, izmjeni uredaba (EZ) br. 663/2009 i (EZ) br. 715/2009 Europskog parlamenta i Vijeća, direktiva 94/22/EZ, 98/70/EZ, 2009/31/EZ, 2009/73/EZ, 2010/31/EU, 2012/27/EU i 2013/30/EU Europskog parlamenta i Vijeća, direktiva Vijeća 2009/119/EZ i (EU) 2015/652 te stavljanju izvan snage Uredbe (EU) br. 525/2013 Europskog parlamenta i Vijeća, SL L 328, 21.12.2018., str. 1-77.

42 Penttinen, Sirja-Leena; Talus, Kim, „Development of the sustainability aspects of EU energy policy“, u: Van Calster, Geert; Vandenberghe, Wim; Reins, Leonie (ur.), Research Handbook on Climate Change Mitigation Law, Edward Elgar Publishing Limited, Cheltenham, 2015., str. 41.

43 Tako Crossley, Penelope, op. cit. (bilj. 32), str. 469.

44 Solorio, Israel; Bocquillon, Pierre, „EU renewable energy policy: a brief overview of its history and evolution“, u: Solorio, Israel; Jörgens, Helge (ur.), A Guide to EU Renewable Energy Policy: Comparing Europeanization and Domestic Policy Change in EU Member States, Edward Elgar Publishing Limited, Cheltenham, 2017., str. 24.

45 Jörgens, Helge; Solorio, Israel, „The EU and the promotion of renewable energy: an analytical framework“, u: Solorio, Israel; Jörgens, Helge (ur.), A Guide to EU Renewable Energy Policy: Comparing Europeanization and Domestic Policy Change in EU Member States, Edward Elgar Publishing Limited, Cheltenham, 2017., str. 3. 
određenoga broja država članica usmjerenih na razvoj fleksibilnog okvira koji bi omogućio širok spektar nacionalnih politika. ${ }^{46}$

Iako začeci europske politike za obnovljive izvore energije sežu u kraj sedamdesetih godina 20. stoljeća, objava Zelene knjige Europske komisije pod naslovom „Energy for the future: renewable sources of energy“ 1996. godine, a potom i Bijele knjige istoga naslova 1997. godine, smatraju se ključnim točkama u njezinoj evoluciji. Nekoliko godina kasnije, Europska komisija predložila je prve dvije direktive usmjerene na promicanje uporabe energije iz obnovljivih izvora. Prva, Direktiva 2001/77/EZ Europskog parlamenta i Vijeća od 27. rujna 2001. o promicanju električne energije proizvedene iz obnovljivih izvora energije na unutarnjem tržištu električne energije, ${ }^{47}$ bila je usmjerena na promicanje obnovljive električne energije, a druga, Direktiva 2003/30/EZ Europskog parlamenta i Vijeća od 8. svibnja 2003. o promicanju uporabe biogoriva ili drugih obnovljivih goriva za prijevoz, ${ }^{48}$ na promicanje biogoriva. Obje su direktive bile usvojene na temelju ovlasti EU-a u području okoliša. ${ }^{49}$

Direktivom 2001/77/EZ određeni su indikativni nacionalni ciljevi država članica za udjele električne energije proizvedene iz obnovljivih izvora do 2010. godine, no u skladu s načelom supsidijarnosti, državama članicama prepušten je izbor programa potpore za postizanje utvrđenih ciljeva. ${ }^{50}$ Budući da Direktivom 2001/77/EZ nisu određeni obvezujući nacionalni ciljevi za države članice, niti je izvršena harmonizacija nacionalnih programa potpore, smatra se da su njezinim konačnim tekstom pružena slaba rješenja u odnosu na najosjetljivija pitanja. Nadalje, Direktivom 2001/77/EZ određena je široka definicija obnovljivih izvora energije, čime je državama članicama olakšano postizanje indikativnih ciljeva. ${ }^{51}$

Direktivom 2003/30/EZ mjere usmjerene na promicanje uporabe energije iz obnovljivih izvora proširene su i na prometni sektor. Prema Direktivi 2003/30/ EZ države članice bile su dužne odrediti nacionalne indikativne ciljeve kako bi se osiguralo da je na njihova tržišta stavljen određeni minimalni udio biogoriva ili drugih obnovljivih goriva. Direktivom su određene i referentne vrijednosti za nacionalne ciljeve, no one nisu bile obvezujuće. ${ }^{52}$

Direktiva 2009/28/EZ Europskog parlamenta i Vijeća od 23. travnja 2009. o promicanju uporabe energije iz obnovljivih izvora te o izmjeni i kasnijem stavljanju

46 Solorio, Israel; Bocquillon, Pierre, op. cit. (bilj. 42), str. 23.

47 Direktiva 2001/77/EZ Europskog parlamenta i Vijeća od 27. rujna 2001. o promicanju električne energije proizvedene iz obnovljivih izvora energije na unutarnjem tržištu električne energije, $S L L 283$, 27.10.2001., str. 33-40. Direktiva je izvan snage od 31. XII. 2011. te nije prevedena na hrvatski jezik.

48 Direktiva 2003/30/EZ Europskog parlamenta i Vijeća od 8. svibnja 2003. o promicanju uporabe biogoriva ili drugih obnovljivih goriva za prijevoz, $S L L$ 123, 17.5.2003., str. 42-46. Direktiva je izvan snage od 31. XII. 2011. te nije prevedena na hrvatski jezik.

49 Solorio, Israel; Bocquillon, Pierre, op. cit. (bilj. 42), str. 24-26.

50 Crossley, Penelope op. cit. (bilj. 32), str. 476.

51 Solorio, Israel; Bocquillon, Pierre, op. cit. (bilj. 42), str. 26-27.

52 Penttinen, Sirja- Leena; Talus, Kim, op. cit. (bilj. 40), str. 43. 
Ivor Šantek, mag. iur. i dr. sc. Lana Ofak: Pravni okvir za obnovljive izvore energije u pravu Europske unije Zbornik radova Pravnog fakulteta u Splitu, god. 57, 3/2020, str. 803-827

izvan snage direktiva 2001/77/EZ i 2003/30/EZ ${ }^{53}$ jedan je od pravnih akata koji predstavljaju drugu generaciju europskog sekundarnog prava za obnovljive izvore energije. ${ }^{54}$ Svrha je Direktive 2009/28/EZ osnaživanje i širenje europskog regulatornog okvira, kao i harmonizacija mjera usmjerenih na povećanje kapaciteta za obnovljivu energiju u svim državama članicama. ${ }^{55} \mathrm{U}$ skladu s općim ciljem povećanja udjela obnovljive energije u konačnoj energetskoj potrošnji na $20 \%$ do 2020. godine, predviđenim strategijom Europa 2020., Direktiva 2009/28/EZ postavlja obvezne nacionalne ciljeve za države članice te ih obvezuje na donošenje nacionalnih akcijskih planova za obnovljivu energiju. ${ }^{56}$ Prema čl. 4. st. 1. Direktive 2009/28/EZ, države članice u nacionalnim akcijskim planovima za obnovljivu energiju moraju odrediti nacionalne ciljeve za udio energije iz obnovljivih izvora koja se koristi u prometu, elektroenergetici te za grijanje i hlađenje za 2020. godinu. Iako niti ovim aktom nije izvršena harmonizacija nacionalnih programa potpore, uvedene su mogućnosti zajedničkih programa potpore, zajedničkih projekata te statističkih prijenosa među državama članicama, koji se računaju u odnosu na nacionalne ciljeve. ${ }^{57}$ U odnosu na prometni sektor, Direktiva 2009/28/EZ određuje da je svaka država članica dužna osigurati da udio energije iz obnovljivih izvora u svim oblicima prometa 2020. godine bude barem $10 \%$ od ukupne potrošnje energije u prometu u konkretnoj državi članici (čl. 3. st. 4.). Energija iz pogonskih biogoriva i drugih tekućih goriva uzima se u obzir u odnosu na nacionalne ciljeve te ispunjava uvjete za nacionalne potpore samo ako udovoljava kriterijima održivosti predviđenima Direktivom 2009/28/EZ..$^{58}$ Ističe se da su u tijeku provedbe Direktive 2009/28/EZ u brojnim državama članicama i dalje bili prisutni problemi administrativnih prepreka, usporenog odobravanja te razvoja infrastrukture nužne za pružanje potpore povećanoj uporabi energije iz obnovljivih izvora, kao i kašnjenja u povezivanju novih proizvođača obnovljive energije, tj. da u tim područjima nije ostvaren značajan napredak. Ipak, smatra se da je Direktiva 2009/28/EZ u svim državama članicama bila uspješna u promicanju uporabe energije iz obnovljivih izvora. ${ }^{59}$

53 Direktiva 2009/28/EZ Europskog parlamenta i Vijeća od 23. travnja 2009. o promicanju uporabe energije iz obnovljivih izvora te o izmjeni i kasnijem stavljanju izvan snage direktiva 2001/77/EZ i 2003/30/EZ, SL L 140, 5. VI. 2009., str. 16-62, Posebno izdanje na hrvatskom jeziku: Poglavlje 15 ., sv. 011., str. 39-85.

54 Colcelli, Valentina, ,Overview of the relationship between the Italian Constitutional court and EU Law, with particular reference to the Italian Constitutional court's approach to renewable energy policy“, u: Duić, Dunja; Petrašević, Tunjica (ur.), EU and comparative law issues and challenges series (ECLIC 2). International Scientific Conference. EU Law in context-adjustment to membership and challenges of the enlargement, Josip Juraj Strossmayer University of Osijek, Faculty of Law Osijek, Osijek, 2018., str. 71 .

55 Sokołowski, Maciej M., „European Law on the Energy Communities: a Long Way to a Direct Legal Framework“, European Energy and Environmental Law Review, god. 27, br. 2, 2018., str. 63.

56 Tako Penttinen, Sirja-Leena; Talus, Kim, op. cit. (bilj. 40), str. 44.

57 Solorio, Israel; Bocquillon, Pierre, op. cit. (bilj. 42), str. 33.

58 Banja, Manjola; Sikkema, Richard; Jégard, Martin; Motola, Vincenzo; Dallemand, Jean-François, „Biomass for energy in the EU - The support framework“, Energy Policy, god. 131, 2019., str. 216.

59 Crossley, Penelope op. cit., (bilj. 32), str. 479. 


\section{2. „Čista energija za sve Europljane“}

\subsubsection{Opseg regulatornog paketa}

Regulatornim paketom „Čista energija za sve Europljane“ izvršena je opsežna prilagodba europskog pravnog okvira za energetsku politiku u svrhu olakšavanja energetske tranzicije od fosilnih goriva prema čišćoj energiji te ispunjavanja obveza EU-a predviđenih Pariškim sporazumom od 12. prosinca 2015. godine. Paket je usvojen na temelju prijedloga Europske komisije objavljenih u studenom 2016. godine, nakon političkog sporazuma postignutog u Europskom parlamentu i Vijeću tijekom 2018. te početkom 2019. godine, čime je omogućeno da svih osam akata sadržanih u paketu stupi na snagu do sredine 2019. godine.$^{60}$ Njime su obuhvaćena područja energetske učinkovitosti, obnovljive energije, tržišta električne energije, sigurnosti opskrbe, kao i pravila o upravljanju energetskom unijom. Tri su glavna cilja paketa: stavljanje energetske učinkovitosti na prvo mjesto, ostvarivanje globalnog vodstva u korištenju energijom iz obnovljivih izvora te pružanje poštenih uvjeta potrošačima. ${ }^{61}$

\subsubsection{Promicanje uporabe energije iz obnovljivih izvora}

Kao sastavnim dijelom paketa „Čista energija za sve Europljane“, Direktivom (EU) 2018/2001 Europskog parlamenta i Vijeća od 11. prosinca 2018. o promicanju uporabe energije iz obnovljivih izvora, ${ }^{62}$ kojom je preinačena Direktiva 2009/28/ EZ, nastoji se postići cilj promicanja obnovljivih oblika energije (recitali 1. - 2. Direktive 2018/2001). U tu svrhu, Direktiva 2018/2001 utvrđuje zajednički okvir za promicanje energije iz obnovljivih izvora (čl. 1.). Energiju iz obnovljivih izvora Direktiva 2018/2001 definira kao energiju iz obnovljivih nefosilnih izvora (čl. 2.). ${ }^{63}$ U interesu jasnoće i pravne sigurnosti, navedena definicija odgovara definicijama za različite vrste energije iz obnovljivih izvora koje su predviđene već spomenutim direktivama 2001/77/EZ te 2003/30/EZ, kao i Direktivom 2009/28/EZ (recital 15. Direktive 2018/2001).

Za razliku od Direktive 2009/28/EZ, koja u skladu s općim ciljem povećanja udjela obnovljive energije u konačnoj energetskoj potrošnji na $20 \%$ do 2020. godine, predviđenim strategijom Europa 2020., postavlja obvezne nacionalne

${ }^{60}$ Clean energy for all Europeans package, http://ec.europa.eu/energy/en/topics/energy-strategyand-energy-union/clean-energy-all-europeans, pristup: 17. kolovoza 2019.

${ }_{61}$ European Commission, Communication from the Commission to the European Parliament, the Council, the European Economic and Social Committee, the Committee of the Regions and the European Investment Bank, Clean Energy For All Europeans, COM(2016) 860 final, Brussels, 30. XI. 2016., http://eur-lex.europa.eu/resource.html?uri=cellar:fa6ea15b-b7b0-11e6-9e3c-01aa75ed71a1.0001.02/ DOC_1\&format=PDF, pristup: 17. kolovoza 2019.

${ }_{62}$ Direktiva 2018/2001 Europskog parlamenta i Vijeća od 11. prosinca 2018. o promicanju uporabe energije iz obnovljivih izvora, SL L 328, 21. XII. 2018., str. 82-209.

63 Prema čl. 2. Direktive 2018/2001 energijom iz obnovljivih izvora smatra se primjerice energija vjetra, solarna energija (toplinska i fotonaponska) te geotermalna energija, energija iz okoliša, energija plime, oseke i druga energija oceana, hidroenergija, biomasa, plin dobiven od otpada, plin dobiven iz uređaja za obradu otpadnih voda i bioplin. 
ciljeve za države članice, ${ }^{64}$ Direktiva 2018/2001 predviđa da su države članice dužne zajednički osigurati da udio energije iz obnovljivih izvora u ukupnoj konačnoj bruto potrošnji energije u EU-u 2030. godine bude najmanje $32 \%$. Osim toga, države članice dužne su, kao dio svojih integriranih nacionalnih energetskih i klimatskih planova predviđenih ranije spomenutom Uredbom 2018/1999, odrediti nacionalne doprinose kako bi skupno ostvarile navedeni obvezujući opći cilj EU-a (čl. 3. st. 1. i 2. Direktive 2018/2001) ${ }^{65}$ Ističe se da bi se ovakvim određivanjem obvezujućeg općeg cilja EU-a za obnovljivu energiju do 2030. godine nastavilo poticati razvoj tehnologije za proizvodnju obnovljive energije, a pružila bi se i sigurnost ulagačima. S druge strane, na taj se način državama članicama omogućava veća fleksibilnost pri postizanju njihovih ciljeva smanjenja emisija stakleničkih plinova na troškovno najučinkovitiji način u skladu s njihovim posebnostima, kombinacijama izvora energije i mogućnostima za proizvodnju obnovljive energije (recital 9. Direktive 2018/2001). Smatra se da ovakvo odbacivanje obvezujućih nacionalnih ciljeva za države članice predstavlja djelomičnu, ali značajnu renacionalizaciju politike u području obnovljive energije, no takvu koja ne sprečava Europsku komisiju u nastojanjima za ostvarivanjem harmonizacije primjenom drugih sredstava. Može se dakle očekivati da će se tenzija između nastojanja za harmonizacijom, s jedne strane, te nacionalnom kontrolom, s druge strane, zadržati. ${ }^{66}$ Nadalje, tvrdi se da bez utvrđivanja obvezujućih nacionalnih ciljeva za države članice nije jasan način ostvarivanja obvezujućeg općeg cilja EU-a, kao niti potencijalne posljedice za države članice koje ne bi surađivale u njegovu ostvarivanju. ${ }^{67}$ Posebno se ističe da je osnovna svrha pravnog okvira koji obuhvaća i obvezujuće ciljeve za obnovljivu energiju pružiti poslovnoj zajednici dugoročnu stabilnost te pravnu sigurnost koje su nužne za sigurne i racionalne investicije u sektoru obnovljive energije. ${ }^{68}$

Prema čl. 4. st. 1. Direktive 2018/2001, kako bi se postigao ili premašio navedeni obvezujući opći cilj EU-a za obnovljivu energiju, ali i nacionalni doprinosi određeni integriranim nacionalnim energetskim i klimatskim planovima, države članice mogu primjenjivati programe potpore. Naime, od devedesetih godina 20. stoljeća, sve veći broj država članica uspostavlja programe potpore, usmjerene na razvoj obnovljive energije, osobito u sektoru električne energije. ${ }^{69}$ Prve posebne programe potpore za obnovljivu energiju u sektoru električne energije uspostavile su Danska, Portugal, Njemačka te Ujedinjeno Kraljevstvo, dok danas takve programe potpore imaju

64 Tako Penttinen, Sirja-Leena; Talus, Kim, op. cit. (bilj. 40), str. 44.

65 Čl. 3. st. 1. Direktive 2018/2001 predviđa mogućnost povećanja obvezujućeg općeg cilja.

66 Tako Solorio, Israel; Bocquillon, Pierre, op. cit. (bilj. 42), str. 38., u kontekstu analize okvira za klimatsku i energetsku politiku 2030.

67 Tako Crossley, Penelope, op. cit. (bilj. 32), str. 483., u kontekstu analize okvira za klimatsku i energetsku politiku 2030.

68 Leal-Arcas, Rafael; Caruso, Valentina; Leupuscek, Raphaela, „Renewables, Preferential Trade Agreements and EU Energy Security“, Laws, god. 4, br. 3, 2015., str. 479.

69 Howes, Tom, „The EU's New Renewable Energy Directive (2009/28/EC)“, u: Oberthür, Sebastian; Pallemaerts, Marc (ur.), The New Climate Policies of the European Union: Internal Legislation and Climate Diplomacy, VUBPress, Brussels, 2010., str. 120. 
predviđene sve države članice. ${ }^{70}$ Pojam ,programa potpore“ definiran je Direktivom 2018/2001 te znači svaki instrument, program ili mehanizam koji primjenjuje država članica ili skupina država članica kojim se potiče uporaba energije iz obnovljivih izvora smanjenjem troškova te energije, povećanjem cijene po kojoj se može prodati ili povećanjem količine nabavljene energije na temelju obveze povezane s obnovljivom energijom ili na drugi način (čl. 2.). Programi potpore obuhvaćaju mjere investicijske potpore (npr. oslobađanje od poreza) te operativne potpore (npr. programi zaštite cijena, programi koji primjenjuju zelene certifikate), pri čemu najčešći oblik potpore predstavljaju mjere operativne potpore. ${ }^{71}$

Tako primjerice tarife za opskrbu energijom (eng. feed-in tariffs), koje s udjelom primjene među državama članicama od $85 \%$ 2010. godine predstavljaju dominantni oblik programa potpore, u pravilu predviđaju da su proizvođači električne energije iz obnovljivih izvora izuzeti od sudjelovanja na tržištu te imaju pravo na garantiranu otkupnu cijenu po dostavljanju električne energije subjektu (često operatoru prijenosnog ili distribucijskog sustava) kod kojeg postoji obveza njezina preuzimanja po garantiranoj cijeni. Garantirana cijena određuje se ili za određeni rok, ili za unaprijed određenu proizvodnju električne energije. ${ }^{72}$

Nadalje, plaćanje premija (eng. premium payments), oblik programa potpore koji je prvi put uveden u Danskoj 2003. godine, a postupno dobiva na značaju i u drugim državama članicama, obuhvaća garantirane premije koje se isplaćuju kao fiksni ili promjenjivi dodatak tržišnoj cijeni električne energije iz obnovljivih izvora. Premije se u pravilu garantiraju za određeni rok ili za unaprijed određenu proizvodnju električne energije. ${ }^{73}$

Konačno, programi potpore za obveze povezane s obnovljivom energijom koji primjenjuju zelene certifikate (eng. renewable energy obligation support schemes using green certificates ili quota obligations with green certificates) predviđaju obvezu za potrošače, opskrbljivače ili proizvođače električne energije, da pribavljaju

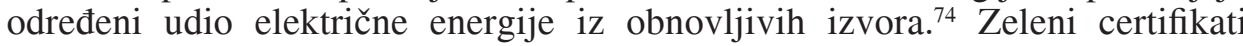
predstavljaju proizvodnju određenog dijela električne energije iz obnovljivih izvora (npr. 1 MWh električne energije proizvedene iz obnovljivih izvora predstavlja 1 zeleni certifikat), a njima se javnoj vlasti dokazuje postupanje u skladu s obvezom povezanom s obnovljivom energijom. Zelenim certifikatima može se slobodno trgovati na tržištu. ${ }^{75}$

70 Kitzing, Lena; Mitchell, Catherine; Morthorst, Poul Erik, ,Renewable energy policies in Europe: Converging or diverging?“" Energy Policy, god. 51, 2012., str. 193.

${ }^{71}$ Howes, Tom, op. cit. (bilj. 67), str. 120.

72 Kitzing, Lena; Mitchell, Catherine; Morthorst, Poul Erik, op. cit. (bilj. 68), str. 194-196.

73 Ibid.

74 Howes, Tom, op. cit. (bilj. 67), str. 121.

75 Kitzing, Lena; Mitchell, Catherine; Morthorst, Poul Erik, op. cit. (bilj. 68), str. 195. Dakako, navedenim razmatranjima nisu obuhvaćeni svi programi potpore za obnovljivu energiju, već samo određeni dominantni oblici. Opširnije o tome Kitzing, Lena; Mitchell, Catherine; Morthorst, Poul Erik, op. cit. (bilj. 68). 
$\mathrm{U}$ pogledu programa potpore, ističe se stav Europske komisije, iskazan u prijedlogu za revidiranu direktivu o promicanju uporabe energije iz obnovljivih izvora (odnosno Direktivu 2018/2001), prema kojem bi propuštanje implementacije koordiniranijeg pristupa promicanju obnovljive energije, nastavljanjem nacionalnih programa potpore, imalo ozbiljne posljedice za potrošače. Takav bi pristup rezultirao manje učinkovitim promicanjem obnovljive energije, koncentracijom investicija u području obnovljive energije u tri države članice, kao i rastom prosječne cijene električne energije za $25 \%$ do 2030. godine, u odnosu na 2010. godinu.$^{76} \mathrm{U}$ vezi s time je i stav Europske komisije prema kojem upravo nacionalni programi potpore država članica potiču većinu razvoja u području obnovljive energije u EU-u, pri čemu se programima potpore omogućuje uzimanje u obzir i nacionalnih te regionalnih specifičnosti, no potencijalno po cijenu tržišne integracije te ekonomičnosti. Europska komisija stoga smatra da bi se u odnosu na divergentne nacionalne programe potpore trebala provesti racionalizacija u svrhu veće usklađenosti s unutarnjim tržištem. ${ }^{77}$ Ipak, navodi se da je u kontekstu postojanja indikacija za „,bottom-up“ konvergenciju nacionalnih programa potpore država članica, usmjerenih na razvoj obnovljive energije u sektoru električne energije, Europska komisija postala fleksibilnija po pitanju nacionalnih programa potpore te njihove ,top-down“ harmonizacije, čime je otvoren put razvoju najbolje prakse. Smatra se da bi zbog takvog razvoja događaja harmonizacija nacionalnih programa potpore na razini EU-a mogla postati nepotrebna ili barem manje kontroverzna. ${ }^{78}$

Tako Direktiva 2018/2001 predviđa da, uz određene uvjete, države članice mogu otvoriti sudjelovanje u programima potpore za električnu energiju iz obnovljivih izvora proizvođačima iz drugih država članica (čl. 5. st. 1.). Smatra se da se omogućivanjem prekograničnog sudjelovanja u programima potpore ograničavaju negativni utjecaji na unutarnje tržište energije te da se time, uz određene pretpostavke, državama članicama može pomoći da troškovno učinkovitije postignu obvezujući opći cilj EU-a. Nadalje, prekogranično sudjelovanje smatra se prirodnim nastavkom razvoja politike EU-a u području obnovljive energije, kojom se potiče konvergencija i suradnja s ciljem doprinosa obvezujućem općem cilju EU-a (recital 23. Direktive 2018/2001). Pri tome, kako bi se osiguralo da je otvaranje programa potpore uzajamno te da nosi obostrane koristi, države članice koje u tome sudjeluju trebale bi potpisati sporazume o suradnji (recital 24. Direktive 2018/2001). ${ }^{79}$

Stav je Europske komisije da je za integraciju električne energije iz obnovljivih izvora u energetski sustav nužna koordinacija potpora među državama članicama ${ }^{80}$

76 Crossley, Penelope, op. cit. (bilj. 32), str. 483.

77 Penttinen, Sirja-Leena; Talus, Kim, op. cit. (bilj. 340), str. 45.

78 Kitzing, Lena; Mitchell, Catherine; Morthorst, Poul Erik, op. cit. (bilj. 68), str. 201.

79 Čl. 5. st. 5. Direktive 2018/2001 predviđa da je Europska komisija do 2023. godine dužna provesti ocjenu provedbe članka kojim je predviđena mogućnost otvaranja programa potpora. U okviru takve ocjene Europska je komisija dužna procijeniti potrebu za uvođenjem obveze za države članice da djelomično otvore sudjelovanje u svojim programima potpora za električnu energiju iz obnovljivih izvora proizvođačima smještenima u drugim državama članicama s ciljem otvaranja od $5 \%$ do 2025 . godine te otvaranja od $10 \%$ do 2030 . godine.

80 Kitzing, Lena; Mitchell, Catherine; Morthorst, Poul Erik, op. cit. (bilj. 68), str. 200. 
Tako Direktiva 2018/2001 sadrži odredbe o statističkim prijenosima među državama članicama (čl. 8.), zajedničkim projektima država članica (čl. 9. - 10.) te zajedničkim programima potpore (čl. 13.). Korištenjem navedenih mehanizama kooperacije, državama članicama omogućuje se veća fleksibilnost u pogledu načina postizanja obvezujućeg općeg cilja EU-a, kao i nacionalnih doprinosa tom cilju. ${ }^{81}$

Mogućnost statističkih prijenosa među državama članicama proizlazi iz čl. 8 . st. 1. Direktive 2018/2001, prema kojem države članice mogu postići dogovor o statističkom prijenosu određene količine energije iz obnovljivih izvora iz jedne države članice u drugu. Pri tome se prenesena količina energije odbija od količine energije iz obnovljivih izvora koja se uzima u obzir pri izračunu udjela obnovljive energije države članice koja obavlja prijenos, a dodaje se količini energije iz obnovljivih izvora koja se uzima u obzir pri izračunu udjela obnovljive energije države članice koja prihvaća prijenos (čl. 8. st. 1. Direktive 2018/2001). Statistički je prijenos energije iz obnovljivih izvora virtualan, odnosno nije praćen i stvarnim prijenosom energije. ${ }^{82}$

Prema čl. 9. st. 1. Direktive 2018/2001, dvije ili više država članica mogu surađivati na svim vrstama zajedničkih projekata koji se odnose na proizvodnju električne energije te grijanja ili hlađenja iz obnovljivih izvora, a takva suradnja može uključivati i privatne operatore. Tako široko određeni institut zajedničkog projekta obuhvaća izgradnju ili sufinanciranje infrastrukture, ali i ugovore o kupoprodaji energije. ${ }^{83}$ Navedenim institutom državama članicama se omogućuje zajedničko određivanje okvira za provedbu projekata. ${ }^{84}$

U pogledu zajedničkih programa potpore, čl. 13. st. 1. Direktive 2018/2001 određuje da dvije ili više država članica mogu dobrovoljno odlučiti udružiti svoje nacionalne programe potpore ili ih djelomično uskladiti. U tim slučajevima, i pod uvjetima predviđenim Direktivom 2018/2001, određena količina energije iz obnovljivih izvora proizvedena na državnom području jedne države članice sudionice može se smatrati dijelom udjela obnovljive energije druge države članice sudionice (čl. 13. st. 1. Direktive 2018/2001). Naime, energija iz obnovljivih izvora koja je proizvedena primjenom navedenog instituta smatra se zajedničkom, te se može dijeliti među državama članicama sudionicama primjenom instituta statističkog prijenosa ili na temelju pravila distribucije koje su države članice sudionice dogovorile..$^{85}$

Direktiva 2018/2001 sadrži i posebna pravila o jamstvu o podrijetlu energije iz obnovljivih izvora (čl. 19.). Pri tome se navodi da je jedina namjena takvih jamstava, izdanih za potrebe Direktive 2018/2001, dokazati krajnjem korisniku da

81 Slično Ibid., u kontekstu analize Direktive 2009/28/EZ.

82 Tako i Howes, Tom, op. cit. (bilj. 67), str. 132., o statističkim prijenosima na temelju Direktive 2009/28/EZ

83 Tako i Ibid., str. 133., o zajedničkim projektima država članica na temelju Direktive 2009/28/EZ.

${ }^{84}$ Tako i Kitzing, Lena; Mitchell, Catherine; Morthorst, Poul Erik, op. cit. (bilj. 68), str. 200., u kontekstu analize Direktive 2009/28/EZ.

85 Slično Howes, Tom, op. cit. (bilj. 67), str. 134., o zajedničkim programima potpore na temelju Direktive 2009/28/EZ. 
je određeni udio ili određena količina energije proizvedena iz obnovljivih izvora (recital 55. Direktive 2018/2001). U tu svrhu države članice dužne su osigurati da se podrijetlo energije iz obnovljivih izvora kao takve u smislu Direktive 2018/2001 može zajamčiti u skladu s objektivnim, transparentnim i nediskriminirajućim kriterijima (čl. 19. st. 1. Direktive 2018/2001).

Direktivom 2018/2001 predviđena su i pravila o uključivanju obnovljive energije u sektor grijanja i hlađenja (čl. 23.). Naime, smatra se da je sektor grijanja i hlađenja, za koje se troši približno pola konačne potrošnje energije u EU-u, ključni sektor u dekarbonizaciji energetskog sektora (recital 73. Direktive 2018/2001). Zbog toga, kako bi promicala uporabu obnovljive energije i u sektoru grijanja i hlađenja, svaka država članica dužna je nastojati povisiti udio obnovljive energije u tom sektoru okvirno za 1,3 postotna boda kao godišnji prosjek izračunat za razdoblja od 2021. do 2025. i od 2026. do 2030., polazeći od udjela obnovljive energije u sektoru grijanja i hlađenja u 2020. godini (čl. 23. st. 1. Direktive 2018/2001). ${ }^{86}$

Radi uključivanja uporabe energije iz obnovljivih izvora u sektor prometa, Direktiva 2018/2001 određuje da je svaka država članica dužna odrediti obvezu za opskrbljivače gorivom kako bi osigurala da udio obnovljive energije u konačnoj potrošnji energije u sektoru prometa bude najmanje $14 \%$ do 2030. godine (čl. 25. st. 1.). Smatra se da bi se obvezom država članica da zatraže od opskrbljivača gorivom da dostave ukupan udio goriva iz obnovljivih izvora mogla pružiti sigurnost ulagačima, kao i poticati stalni razvoj alternativnih obnovljivih goriva za promet (recital 83. Direktive 2018/2001). ${ }^{87}$ Nadalje, navodi se da bi se biogoriva, tekuća biogoriva i goriva iz biomase trebala uvijek proizvoditi na održiv način (recital 94. Direktive 2018/2001). Zbog toga se energija iz biogoriva, tekućih biogoriva i goriva iz biomase uzima u obzir za potrebe doprinosa obvezujućem općem cilju EU-a i udjelima obnovljive energije država članica, ocjenjivanja poštovanja obveza povezanih s obnovljivom energijom te prihvatljivosti za financijsku potporu, samo ako ispunjavaju kriterije održivosti i uštede emisija stakleničkih plinova predviđene Direktivom 2018/2001 (čl. 29. st. 1. Direktive 2018/2001).

Konačno, pri provedbi Direktive 2018/2001 trebalo bi, ako je to relevantno, uzeti u obzir i Konvenciju o pristupu informacijama, sudjelovanju javnosti pri odlučivanju i pristupu pravosuđu u pitanjima okoliša od 25. lipnja 1998. godine (recital 125. Direktive 2018/2001).

Smatra se da se promicanjem uporabe energije iz obnovljivih izvora danas nastavlja važna uloga koju su pitanja iz područja energije zauzimala u povijesnom procesu europske integracije. ${ }^{88}$ Pored toga, ostvarivanje rasta u sektoru obnovljive energije značajno je za ostvarivanje ciljeva europske klimatske i energetske politike.

86 Navedeno povećanje ograničava se na okvirni 1,1-postotni bod za države članice u kojima se ne upotrebljava otpadna toplina i hladnoća (čl. 23. st. 1. Direktive 2018/2001).

${ }_{87}$ Pored toga, recital 85. Direktive 2018/2001 predviđa da je obveza država članica da od opskrbljivača gorivom zahtijevaju osiguranje minimalnog udjela naprednih biogoriva i određenih bioplinova namijenjena poticanju stalnog razvoja naprednih goriva, uključujući biogoriva.

88 Jörgens, Helge; Solorio, Israel, op. cit. (bilj. 43), str. 4. 
Zbog toga se pravni okvir predviđen Direktivom 2018/2001, kao i ranijom Direktivom 2009/28/EZ, nastavlja na iskustvo ranijeg sekundarnog prava za obnovljivu energiju, kao i prava usmjerenog na suočavanje s klimatskim promjenama. ${ }^{89}$

Smatra se da EU ima vodeću ulogu u svijetu u promicanju uporabe energije iz obnovljivih izvora. Ipak, brojni kritičari tvrde da određena obilježja okvira za klimatsku i energetsku politiku 2030., osobito odbacivanje obvezujućih nacionalnih ciljeva država članica za energiju iz obnovljivih izvora, odnosno ograničavanje sporazuma na određivanje obvezujućeg općeg cilja EU-a, ugrožavaju takvu ulogu, kao i ideju ,zelene“ Europe. ${ }^{90}$

\section{PRAKSA SUDA EUROPSKE UNIJE U PODRUČJU OBNOVLJIVIH IZVORA ENERGIJE}

Komisija je podnijela četiri tužbe protiv država članica zbog propusta provedbe Direktive 2009/28 o promicanju uporabe energije iz obnovljivih izvora (protiv Poljske, Cipra, Austrije i Irske), ali je sve tužbe povukla. Stoga su se slučajevi pred Sudom Europske unije (dalje i: Sud EU-a) koji su se ticali primjene te direktive odnosili samo na prethodna pitanja nacionalnih sudova u vezi s tumačenjem njezinih pojedinih odredaba. Ta će Direktiva biti na snazi do 30. lipnja 2021., a od 1. srpnja 2021. države članice će obvezivati nova Direktiva 2018/2001.

Do dana završetka našeg istraživanja Sud EU-a donio je osam presuda u kojima je pojasnio značenje odredaba Direktive 2009/28. Tablica 1. sadrži njihov sažet prikaz, a u tablici 2. naznačeni su predmeti koji su trenutno još uvijek u tijeku.

Tablica 1.

Prikaz presuda Suda EU-a u pogledu tumačenja Direktive 2009/28

\begin{tabular}{|l|l|l|}
\hline $\begin{array}{l}\text { Otpadne vode kao } \\
\text { obnovljiv izvor } \\
\text { energije }\end{array}$ & C-4/16 J.D. & $\begin{array}{l}\text { Pojam ,energija iz obnovljivih } \\
\text { izvora” treba tumačiti na način da } \\
\text { uključuje energiju proizvedenu u maloj } \\
\text { hidroelektrani koja nije crpna ni protočna } \\
\text { s crpnom funkcijom i koja se nalazi } \\
\text { na mjestu ispuštanja otpadnih voda } \\
\text { drugog postrojenja koje je prethodno } \\
\text { upotrijebilo vodu za vlastite potrebe }\end{array}$ \\
\hline $\begin{array}{l}\text { Primjena strožih } \\
\text { pravila od onih } \\
\text { koja su propisana } \\
\text { direktivom }\end{array}$ & C-2/10 Franchini & $\begin{array}{l}\text { Članak 193. UFEU-a omogućava da } \\
\text { države članice mogu usvojiti strože } \\
\text { mjere zaštite na području ekološke mreže } \\
\text { Natura 2000 (zabrana vjetroelektrana) }\end{array}$ \\
\hline
\end{tabular}

89 Slično Howes, Tom, op. cit. (bilj. 67), str. 144., u kontekstu analize Direktive 2009/28/EZ.

90 Slično Jörgens, Helge; Solorio, Israel, op. cit. (bilj. 43), str. 4. 


\begin{tabular}{|c|c|c|}
\hline $\begin{array}{l}\text { Regionalna pristojba } \\
\text { na vjetroagregate }\end{array}$ & $\begin{array}{l}\text { C-215/16 Elecdey } \\
\text { Carcelen }\end{array}$ & $\begin{array}{l}\text { Ubiranje pristojbe na vjetroagregate koji } \\
\text { služe za proizvodnju električne energije } \\
\text { nije protivno Direktivi 2009/28 }\end{array}$ \\
\hline $\begin{array}{l}\text { Posebni uvjeti } \\
\text { za certificiranje } \\
\text { održivosti biogoriva }\end{array}$ & $\begin{array}{l}\text { C-242/17 L. E. G. } \\
\text { O. }\end{array}$ & $\begin{array}{l}\text { Posebni uvjeti za certificiranje održivosti } \\
\text { biogoriva, različiti i širi od onih koji } \\
\text { su predviđeni u dobrovoljnom sustavu } \\
\text { certificiranja održivosti, nisu protivni } \\
\text { Direktivi 2009/28 }\end{array}$ \\
\hline $\begin{array}{l}\text { Nacionalni } \\
\text { program potpore } \\
\text { za postrojenja } \\
\text { koja proizvode } \\
\text { električnu energiju } \\
\text { iz obnovljivih izvora } \\
\text { energije }\end{array}$ & $\begin{array}{l}\text { C-573/12 Ålands } \\
\text { Vindkraft }\end{array}$ & $\begin{array}{l}\text { Države članice nisu obvezne podupirati } \\
\text { proizvodnju energije iz obnovljivih } \\
\text { izvora u drugim državama Unije }\end{array}$ \\
\hline $\begin{array}{l}\text { Uvoz bioplina iz } \\
\text { druge države članice }\end{array}$ & $\begin{array}{l}\text { C-549/15 E.ON } \\
\text { Biofor }\end{array}$ & $\begin{array}{l}\text { Mjera koju je donijela Agencija za } \\
\text { energiju kojom se ograničava uvoz } \\
\text { bioplina iz drugih država članica putem } \\
\text { međusobno povezane mreže nacionalnih } \\
\text { plinovoda nije u skladu s člankom } \\
\text { 34. Ugovora o funkcioniranju EU-a } \\
\text { jer nerazmjerno ograničava slobodno } \\
\text { kretanje robe }\end{array}$ \\
\hline $\begin{array}{l}\text { Obveza otkupa } \\
\text { električne energije } \\
\text { koju proizvode } \\
\text { postrojenja koja se } \\
\text { koriste mehaničkom } \\
\text { energijom vjetra po } \\
\text { cijeni višoj od tržišne }\end{array}$ & $\begin{array}{l}\text { C-262/12 } \\
\text { Association Vent de } \\
\text { colère! Fédération } \\
\text { nationale }\end{array}$ & $\begin{array}{l}\text { Mehanizam potpune naknade dodatnih } \\
\text { troškova nametnutih poduzećima zbog } \\
\text { obveze otkupa električne energije iz } \\
\text { vjetra po cijeni višoj od tržišne, koju } \\
\text { financiraju svi krajnji kupci električne } \\
\text { energije na državnom području, } \\
\text { predstavlja povredu članka 107. stavka } 1 . \\
\text { Ugovora o funkcioniranju EU-a (državne } \\
\text { potpore) }\end{array}$ \\
\hline $\begin{array}{l}\text { Izmjena programa } \\
\text { potpore }\end{array}$ & $\begin{array}{l}\text { C-180/18, C-286/18 } \\
\text { i C-287/18 } \\
\text { Agrenergy i } \\
\text { Fusignano Due }\end{array}$ & $\begin{array}{l}\text { Nacionalno zakonodavstvo poput onoga } \\
\text { u glavnom postupku koje dopušta } \\
\text { državi članici da predvidi smanjenje } \\
\text { ili i ukidanje prethodno utvrđenih } \\
\text { poticajnih tarifa za energiju proizvedenu } \\
\text { u fotonaponskim solarnim postrojenjima } \\
\text { nije protivno Direktivi } 2009 / 28\end{array}$ \\
\hline
\end{tabular}


Tablica 2.

Postupci u pogledu tumačenja Direktive 2009/28 u tijeku

\begin{tabular}{|l|l|l|}
\hline $\begin{array}{l}\text { Ograničavanje } \\
\text { postavljanja } \\
\text { vjetroelektrana } \\
\text { uvođenjem propisa o } \\
\text { najmanjoj udaljenosti } \\
\text { vjetroelektrane od } \\
\text { stambenog objekta ili } \\
\text { objekta s mješovitom } \\
\text { funkcijom koja } \\
\text { uključuje i stambenu } \\
\text { funkciju }\end{array}$ & $\begin{array}{l}\text { C-727/17 ECO- } \\
\text { WIND Construction }\end{array}$ & $\begin{array}{l}\text { Je li ograničavanje postavljanja } \\
\text { vjetroelektrana uvođenjem propisa o } \\
\text { najmanjoj udaljenosti vjetroelektrane } \\
\text { od stambenog objekta ili objekta s } \\
\text { mješovitom funkcijom koja uključuje } \\
\text { i stambenu funkciju, prema kojem ta } \\
\text { udaljenost treba biti ista ili veća od } \\
\text { deseterostruke visine vjetroelektrane } \\
\text { mjerene od razine tla do najviše točke } \\
\text { objekta uključujući tehničke elemente } \\
\text { osobito rotor s lopaticama, u skladu s } \\
\text { Direktivom 2009/28? }\end{array}$ \\
\hline $\begin{array}{l}\text { Porez na vrijednost } \\
\text { proizvodnje } \\
\text { električne energije }\end{array}$ & $\begin{array}{l}\text { C-220/19 } \\
\text { Promociones Oliva } \\
\text { Park }\end{array}$ & $\begin{array}{l}\text { Je li porez na vrijednost proizvodnje } \\
\text { električne energije u skladu s Direktivom } \\
\text { 2009/28? }\end{array}$ \\
\hline $\begin{array}{l}\text { Smanjenje ili odgoda } \\
\text { isplate poticaja } \\
\text { već dodijeljenih } \\
\text { zakonom i } \\
\text { definiranih na } \\
\text { temelju posebnih } \\
\text { ugovora }\end{array}$ & $\begin{array}{l}\text { C-798/18 } \\
\text { Federazione ANIE } \\
\text { C-306/19 Milis } \\
\text { Energy } \\
\text { C-512/19 Go Sun i } \\
\text { Malby Energy } 4 \\
\text { C-595/19 Fototre }\end{array}$ & $\begin{array}{l}\text { Protivi li se pravu Europske unije } \\
\text { primjena nacionalne odredbe koja znatno } \\
\text { smanjuje ili odgađa isplatu poticaja } \\
\text { već dodijeljenih zakonom i definiranih } \\
\text { na temelju posebnih ugovora koje su } \\
\text { proizvođači fotonaponske električne } \\
\text { energije sklopili s trgovačkim društvom } \\
\text { u javnom vlasništvu? }\end{array}$ \\
\hline $\begin{array}{l}\text { Prijevremeno } \\
\text { ukidanje zakonom } \\
\text { propisanih mjera } \\
\text { za promicanje } \\
\text { proizvodnje } \\
\text { električne energije } \\
\text { iz obnovljivih izvora } \\
\text { koje se odnose na } \\
\text { dugoročne ugovore } \\
\text { o kupnji električne } \\
\text { energije }\end{array}$ & $\begin{array}{l}\text { C-366/19 } \\
\text { BOSOLAR }\end{array}$ & $\begin{array}{l}\text { Je li mijenjanje povlaštenih uvjeta za } \\
\text { kupnju električne energije iz obnovljivih } \\
\text { izvora i u pogledu dugoročnih ugovora } \\
\text { o kupnji električne energije koji su } \\
\text { već sklopljeni u skladu s prvobitno } \\
\text { donesenim nacionalnim mjerama za } \\
\text { prenošenje Direktive 2009/28 u skladu s } \\
\text { pravom EU-a? }\end{array}$ \\
\hline
\end{tabular}

U predmetu C-4/16 J. D. riječ je bila o poduzetniku koji se koristio koncesijom za proizvodnju električne energije iz obnovljivih izvora. Koncesija je konkretno obuhvaćala dvije termoelektrane na bioplin i jednu malu hidroelektranu koja se nalazi na području ispuštanja otpadnih voda iz drugog postrojenja koje nije uključeno u proizvodnju električne energije. Kada je zatražio produljenje koncesije, njegov je zahtjev bio odbijen uz obrazloženje da se ,samo za hidroelektrane koje 
se koriste energijom valova, morskih struja, plime i oseke i riječnih struja može smatrati da proizvode energiju iz obnovljivih izvora". Kada je predmet povodom pravnih lijekova došao pred Žalbeni sud u Varšavi, taj je sud postavio prethodno pitanje Sudu EU-a. Kako je pojasnio nezavisni odvjetnik, sporna hidroelektrana koristi se otpadnim vodama koje je ispustila treća osoba, neovisno o aktivnosti postrojenja i potpuno nepovezano s proizvodnjom električne energije. Prema tome, nije riječ o crpnoj hidroelektrani nego o centrali koja se za proizvodnju električne energije koristi vodom koja bi u protivnom otekla bez naknadnog gospodarskog iskorištavanja ili koristi za okoliš. Centrala se koristi otpadnim vodama koje ne bi imale drugu svrhu osim ispuštanja tako da je njezino dodatno korištenje u proizvodnji električne energije korisno za okoliš. ${ }^{11}$ Sud EU-a je prihvatio mišljenje nezavisnog odvjetnika te je na postavljeno pitanje odgovorio da pojam ,energija iz obnovljivih izvora" iz članka 2. drugog stavka točke (a) Direktive 2009/28 treba tumačiti na način da uključuje energiju proizvedenu u maloj hidroelektrani koja nije crpna hidroelektrana ni protočna hidroelektrana s crpnom funkcijom i koja se nalazi na mjestu ispuštanja otpadnih voda drugog postrojenja koje je prethodno upotrijebilo vodu za vlastite potrebe. ${ }^{92}$ Sud je, međutim, dodatno pojasnio da, kako bi se izbjegla opasnost od zaobilaženja propisa, djelatnost koja se obavlja uzvodno, a koja je izvor tog umjetnog protoka vode, ne smije imati za jedini cilj stvaranje spomenutog protoka vode radi njegova korištenja nizvodno za proizvodnju energije. Stoga, prema mišljenju Suda EU-a, pojam hidroenergije iz obnovljivih izvora u smislu Direktive 2009/28 ne obuhvaća električnu energiju proizvedenu iz energije vode dobivene umjetnim protokom vode ako je taj protok crpljenjem stvoren uzvodno s jedinim ciljem da se ta električna energija proizvodi nizvodno. ${ }^{93}$

U predmetu C-2/10 Franchini, koji se odnosio na odbijanje odobrenja za postavljanje vjetroturbina u području ekološke mreže Natura 2000, Sud Europske unije utvrdio je da Direktiva 92/43 o očuvanju prirodnih staništa i divlje faune i flore, Direktiva 79/409 o očuvanju divljih ptica i Direktiva 2009/28 o promicanju uporabe energije iz obnovljivih izvora moraju se tumačiti na način da ne sprečavaju strože nacionalne mjere zaštite koje bi nametale potpunu zabranu određene vrste aktivnosti poput postavljana vjetroturbina, bez ikakvih uvjeta da se prethodno mora provesti ocjena prihvatljivosti zahvata ili plana za ekološku mrežu. ${ }^{94}$

O vjetroelektranama odlučivalo se i u predmetu C-215/16 Elecdey Carcelen, a riječ je bila o pristojbama za vjetroagregate. Pristojbu je uvela španjolska regija La Mancha zbog opterećenja i štetnih učinaka na prirodni okoliš i područje koji nastaju uslijed izgradnje vjetroelektrana s vjetrogeneratorima za proizvodnju električne energije. Poduzetnici koji iskorištavaju vjetroelektrane koje podliježu

91 Mišljenje nezavisnog odvjetnika M. Camposa Sánchez-Bordone od 15. studenoga 2016., Predmet C-4/16 J. D. protiv Prezes Urzędu Regulacji Energetyki, ECLI:EU:C:2016:875, par. 41. i 42.

92 Presuda Suda (drugo vijeće) od 2. ožujka 2017., Predmet C-4/16 J. D. protiv Prezes Urzędu Regulacji Energetyki, ECLI:EU:C:2017:153, par. 38.

93 Ibid., par. 36.

94 Presuda Suda (prvo vijeće) od 21. srpnja 2011., Predmet C-2/10 Azienda Agro-Zootecnica Franchini sarl i Eolica di Altamura Srl protiv Regione Puglia, ECLI:EU:C:2011:502, par. 75. 
plaćanju regionalne pristojbe za vjetroagregate zatražili su povrat plaćenih iznosa te je tako nastao spor u kojem je nacionalni upitao Sud EU-a je li ta pristojba u skladu s Direktivom 2009/28. Sud EU-a je utvrdio da, iako pristojba može učiniti manje privlačnom proizvodnju i korištenje vjetroenergije te ugroziti njezin razvoj, uvođenje takve pristojbe ne može se samo po sebi smatrati protivnim Direktivi, s obzirom na to da države članice raspolažu širokom marginom prosudbe za postizanje svog nacionalnog cilja udjela energije iz obnovljivih izvora u bruto neposrednoj potrošnji energije u 2020. ${ }^{5}$ Stoga je Sud EU-a zaključio da nacionalni propisi o ubiranju pristojbe na vjetroagregate koji služe za proizvodnju električne energije nisu protivni Direktivi 2009/28.96

U predmetu C-242/17 L.E.G.O., Sud EU-a morao je odgovoriti na pitanje je li nacionalni sustav certificiranja održivosti tekućih biogoriva sukladan Direktivi 2009/28. Sud EU-a je utvrdio da kada pravo Europske unije ne propisuje odredbe vezane za sve kriterije održivosti, države članice ostaju slobodne nametnuti gospodarskim subjektima poštovanje nacionalnog propisa kojim se želi osigurati kontrola poštovanja navedenih kriterija. ${ }^{97}$ Stoga je zaključio da posebni uvjeti za certificiranje održivosti biogoriva, koji su različiti i širi od onih koji su predviđeni u dobrovoljnom sustavu certificiranja održivosti, nisu protivni Direktivi 2009/28 jer se odnose samo na tekuća biogoriva. ${ }^{98}$

Predmet C-573/12 odnosio se na društvo Ålands Vindkraft koje je zatražilo od švedskih vlasti da mu za vjetroelektranu smještenu na otočju Åland u Finskoj dodijele certifikate električne energije. ${ }^{99}$ Taj zahtjev je odbijen uz obrazloženje da se takvi certifikati električne energije mogu dati samo onima koji koriste postrojenja za proizvodnju zelene električne energije smještena u Švedskoj. Sud EU-a podsjetio je da direktiva ne nameće državama članicama koje su se odlučile za program potpore da njegove pogodnosti prošire na zelenu električnu energiju proizvedenu na području druge države članice te je, stoga, utvrdio da je švedski program potpore u skladu s Direktivom 2009/28. ${ }^{100}$ Sud je također potvrdio da je Švedska, s obzirom na stanje prava Unije u kakvom se trenutno nalazi, legitimno mogla smatrati da bi

95 Presuda Suda (prvo vijeće) od 20. rujna 2017., Predmet C-215/16, Elecdey Carcelen SA i dr. protiv Comunidad Autónoma de Castilla-La Mancha, ECLI:EU:C:2017:705, par. 39. i 40.

96 Ibid., 41.

97 Presuda Suda (drugo vijeće) od 4. listopada 2018., Predmet C-242/17 Legatoria Editoriale Giovanni Olivotto (L.E.G.O.) SpA protiv Gestore dei servizi energetici (GSE) SpA i dr., ECLI:EU:C:2018:804, par. 34.

98 Ibid., 41.

99 Certifikati električne energije mogu se prodavati dobavljačima električne energije ili određenim korisnicima, koji su, pod prijetnjom obveze plaćanja posebne naknade, obvezni imati određenu količinu takvih certifikata koji odgovaraju udjelu u njihovim ukupnim isporukama ili njihovoj ukupnoj potrošnji električne energije. Prodaja tih certifikata omogućuje proizvođačima zelene električne energije ostvarenje dodatnih prihoda, a dodatne troškove proizvodnje električne energije, čiji je trošak proizvodnje još uvijek veći od troška električne energije proizvedene iz neobnovljivih izvora energije, snose dobavljači i potrošači. V. Sud Europske unije, Priopćenje za medije br. 90/14 od 1. srpnja 2014., Presuda u predmetu C-573/12 Ålands Vindkraft AB/Energimyndigheten.

100 Presuda Suda (veliko vijeće) od 1. srpnja 2014., Predmet C-573/12, Ålands Vindkraft AB protiv Energimyndigheten, ECLI:EU:C:2014:2037, par. 53. i 54 
se pogodnosti nacionalnog programa potpore trebale ograničiti samo na nacionalnu proizvodnju zelene električne energije. Sud je osobito istaknuo da je taj program potpore nužan za poticanje, dugoročno gledano, ulaganja u zelenu energiju. ${ }^{101}$

U predmetu C-549/15 E.ON Biofor Sudu EU-a postavljeno je pitanje mora li država članica na temelju članka 18. Direktive 2009/28, kojim se uređuje metoda masene bilance, ${ }^{102}$ prihvatiti održivi bioplin uvezen iz druge države članice putem međusobno povezane mreže nacionalnih plinovoda. Sukladno članku 18. stavku 1. Direktive 2009/28 masena bilanca (dalje: MB) tehnički je postupak za provjeru toga jesu li ispunjeni kriteriji održivosti za bioplin. Ta odredba utvrđuje samo minimalne uvjete koje države članice trebaju uzeti u obzir prilikom primjene metode MB. Sud EU-a na prvo je pitanje odgovorio da se članak 18. stavak 1. Direktive 2009/28 treba tumačiti na način da mu nije cilj stvoriti obvezu državama članicama da odobre uvoz održivog bioplina putem njihovih nacionalnih međusobno povezanih mreža plinovoda. ${ }^{103}$ Međutim, ako država članica dopušta mogućnost upotrebe postupka masene bilance u svojoj nacionalnoj mreži plinovoda, bi li to trebala dopustiti i za uvoz bioplina iz drugih država članica? U pogledu tog drugog pitanja Sud EU-a trebao je utvrditi je li mjera švedske Agencije za energiju, koja dopušta primjenu metode masene bilance u svojoj nacionalnoj mreži plinovoda, ali ne i u prekograničnoj mreži međusobno povezanih plinovoda, u skladu s člankom 34. UFEU-a kojim se jamči sloboda kretanja roba. Sud je odgovorio da takva mjera nije u skladu s člankom 34. jer nerazmjerno ograničava slobodno kretanje robe. ${ }^{104}$

Prethodno pitanje koje je u predmetu C-262/12 Association Vent de colère! Fédération nationale postavio francuski Conseil d'État, odnosilo se na tumačenje jednog od sastavnih kriterija pojma državna potpora, odnosno pojma intervencije države ili intervencije putem državnih sredstava. Riječ je bila o načinu financiranja naknade dodatnih troškova nametnutih opskrbljivačima električnom energijom iz vjetra u Francuskoj zbog obveze otkupa te električne energije po cijeni višoj od tržišne. Dodatni troškovi koji su proizlazili iz obveze otkupa nadoknađivani su iz fonda javne službe za proizvodnju električne energije, kojim je upravljao Depozitni i založni fond i koji se financirao iz doprinosa koje su plaćali proizvođači, dobavljači i opskrbljivači. Međutim, izmjenom zakona propisano je da dodatni troškovi koji proizlaze iz obveze otkupa podliježu naknadi koja se financira iz doprinosa koje plaćaju krajnji kupci električne energije koji se nalaze na državnom području.

101 Ibid., par. 103. i 104.

102 Upotreba bioplina (primjerice kao pogonskog biogoriva za prijevoz) ima povoljne učinke na okoliš ako je dobiven iz organskog otpada, ali može negativno utjecati na druge interese (među ostalim na opskrbu stanovništva hranom ili na biološku raznolikost područja od velikog ekološkog značaja) ako se dobiva iz neotpadnih sirovina. Stoga se Direktivom 2009/28 taj rizik želi spriječiti time što je u njoj utvrđeno da bioplin koji se koristi kao biogorivo za uključivanje u sustav energije iz obnovljivih izvora treba ispunjavati stroge „kriterije održivosti”. Prilikom provjere jesu li ti kriteriji ispunjeni, upotrebljava se metoda koja se zove „masena bilanca”, na koju se odnose pitanja koja je nacionalni sud uputio Sudu EU-a.

103 Presuda Suda (drugo vijeće) od 22. lipnja 2017., Predmet C-549/15 E.ON Biofor Sverige AB protiv Statens energimyndighet, ECLI:EU:C:2017:490, par. 42.

104 Ibid., par. 99. i 100. 
Tužitelji su smatrali da se radi o državnoj potpori u smislu članka 107. stavka 1. UFEU-a. Sud EU-a odgovorio je potvrdno da mehanizam potpune naknade dodatnih troškova nametnutih poduzećima zbog obveze otkupa električne energije iz vjetra po cijeni višoj od tržišne, koju financiraju svi krajnji kupci električne energije na državnom području predstavlja intervenciju putem državnih sredstava.

U spojenim predmetima C-180/18, C-286/18 i C-287/18 Agrenergy i Fusignano Due, tužitelji su u glavnom postupku pred nadležnim Regionalnim upravnim sudom osporavali tzv. Peti energetski račun, koji je znatno smanjio poticaje za proizvodnju električne energije u fotonaponskim solarnim postrojenima. Zatražili su primjenu povoljnije poticajne tarife predviđene tzv. Četvrtim energetskim računom, ističući da njihova postrojenja ispunjavaju uvjete za poticaj predviđen potonjim energetskim računom. Sud EU-a je odgovorio da nacionalno zakonodavstvo koje dopušta državi članici da predvidi smanjenje ili čak i ukidanje prethodno utvrđenih poticajnih tarifa za energiju proizvedenu u fotonaponskim solarnim postrojenjima nije protivno Direktivi 2009/28/EZ, s obzirom na načela pravne sigurnosti i zaštite legitimnih očekivanja. ${ }^{105}$

Postupci u pogledu tumačenja Direktive 2009/28 koji su još uvijek u tijeku pokazuju da su u području obnovljivih izvora energije i dalje vrlo slične teme aktualne, osobito pitanja vezana za nepovoljan utjecaj vjetroelektrana na okoliš te pojašnjenja pod kojim je uvjetima moguće smanjivati poticaje za projekte obnovljivih izvora energije.

\section{ZAKLJUČAK}

U međunarodnopravnom poretku očigledan je nedostatak posebnog pravnog okvira za promicanje uporabe energije iz obnovljivih izvora, a energetska tranzicija $\mathrm{u}$ velikoj je mjeri prepuštena nacionalnim inicijativama. U tom kontekstu osobito je značajna regulatorna djelatnost EU-a, kao nadnacionalnog pravnog i političkog okvira, usmjerena na kreiranje pravnih i političkih inovacija koje nedostaju na međunarodnoj razini.

Naime, pitanja iz područja energije zauzimala su važnu ulogu u povijesnom procesu europske integracije, a tvrdi se da se promicanjem uporabe energije iz obnovljivih izvora takva uloga nastavlja i danas. Takve su okolnosti pogodovale nastanku i razvoju tenzija između nastojanja za europeizacijom energetskog prava i politike te nacionalnog suvereniteta i interesa država članica u energetskom sektoru.

Takve tenzije vidljive su i u razvoju europske politike za obnovljive izvore energije, kako u utvrđivanju ciljeva europske energetske politike u strategijama za tekuće, odnosno naredno desetljeće, tako i u viziji Europske komisije za dugoročnu europsku energetsku strategiju, u kojoj se zagovara paneuropski pristup. Time je

105 Presuda Suda (deseto vijeće) od 11. srpnja 2019., spojeni predmeti C-180/18, C-286/18 i C-287/18 Agrenergy Srl i Fusignano Due Srl protiv Ministero dello Sviluppo Economico, ECLI:EU:C:2019:605, par. 47. 
obilježen i projekt energetske unije, usmjeren, među ostalim, i na dekarbonizaciju europskog gospodarstva.

Navedena je tenzija specifična i za razvoj sekundarnog europskog prava za obnovljive izvore energije. Dok Direktiva 2009/28/EZ, polazeći od općeg cilja povećanja udjela obnovljive energije u konačnoj energetskoj potrošnji, predviđenog strategijom Europa 2020., određuje i obvezne nacionalne ciljeve za države članice, Direktiva 2018/2001 odbacuje obvezne nacionalne ciljeve te se ograničava na postavljanje obvezujućeg općeg cilja EU-a za obnovljivu energiju. Nadalje, iako je Europska komisija, u pogledu organizacije nacionalnih programa potpore za obnovljivu energiju u sektoru električne energije, preferirala implementaciju koordiniranijeg pristupa, uz veću razinu usklađenosti s unutarnjim tržištem te tržišne integracije, danas zauzima fleksibilniji stav u pogledu njihove ,top-down“ harmonizacije, čime je u tom području otvoren put razvoju najbolje prakse, osobito u kontekstu postojanja indikacija za „,bottom-up“ konvergenciju nacionalnih programa potpore država članica. Upravo analiza tendencija u takvoj konvergenciji, kao i primjeni programa potpore u državama članicama, bila bi zanimljivom temom za daljnje istraživanje. Također, pitanje je kako će usvajanje navedenog pristupa utjecati na vodeću svjetsku ulogu EU-a u promicanju uporabe energije iz obnovljivih izvora.

\section{LEGAL FRAMEWORK FOR RENEWABLE ENERGY SOURCES IN EUROPEAN UNION LAW}

The purpose of this paper is to explore the legal framework for renewable energy in EU law. To this end, some key issues in European renewable energy policy will be outlined. The central part of the paper presents an overview of EU secondary law for renewable energy sources, with particular attention to its historical development issues, as well as the new Directive (EU) 2018/2001 on the promotion of the use of energy from renewable sources, which revised the Directive 2009/28/EC. These considerations will also take into account the impact of environmental law on EU energy law. The last part of the paper examines the case law of the Court of Justice of the EU in the field of renewable energy.

Key words: renewable energy sources, Directive (EU) 2018/2001, Directive 2009/28/EC, case law of the CJEU, environmental protection 